\title{
Research on Korean Talent Demand and Training Orientation under the New Normal of Foreign Trade Development
}

\author{
HE Xu-dong \\ School of Management \\ Xuzhou Institute of Technology \\ Jiangsu, China \\ 289031610@qq.com
}

\author{
Zhang Yuan-yuan \\ School of Management \\ Xuzhou Institute of Technology \\ Jiangsu, China \\ guojimaoyi20030421@126.com
}

\begin{abstract}
Combining with the new normal situation of foreign trade development, the paper analyze the new change of the market demand of Korean professional talents from the three points of region distribution, industrial distribution and enterprise demand, discusses the general institutes of higher education how to position the Korean talents training. Based on above the analyses some strategic suggestions related to the Korean talents training in the new normal situation of foreign trade are discussed in the end of the paper. It is important to pay attention to the curriculum system constructing, the construction and guarantee system of professional teacher staff and designing reasonably phases of compound Korean talent cultivation.
\end{abstract}

Keywords—the new normal; Korean talents; inter-disciplinary talent; training orientation

\section{The New Normal of Foreign Trade Growth}

Statistics data released by the general administration of customs shows that in 2014 China's foreign trade import and export growth are only $2.3 \%$, only $3.4 \%$ in dollars, not reaching the official full-year target of $7.5 \%$ set in early 2014 . It also means that China has not achieved the expected goal of foreign trade growth has for three consecutive years since 2012 The main reasons for this phenomenon are the following aspects: Firstly, the world economic recovery is slow, unable to support the rapid growth of China's foreign trade. Secondly, a low cost comparative advantage of China's labor-intensive products has weakened unceasingly. The falling invest from the developed countries in China's manufacturing also suppresses the import and export. Thirdly, a rapid decline of staple commodity prices in the international market pulls down China's imports growth. The fourth reason is risk factors such as the geopolitics and great power relation game [1].

In addition, from the point of the domestic economy, at the end of 2014 the macroeconomic data such as the purchasing managers' index (PMI) and the producer price index (PPI) has dropped sharply. These factors determine the China's foreign trade is entering into the "new normal" state. China's foreign trade has shifted gear from the previous high speed to a medium-to-high speed growth characterized with transformation and upgrading of the structure, including the quality and efficiency, import and export balance problem and the change of enterprise competitiveness, etc.

\section{NEW Changes of MARKET DEMAND FOR KoREAN TALENT}

The economic trade and political cultural exchange has developed rapidly since the relationship between China and South Korea realized normalization in 1992. According to South Korean customs statistics in 2014, South Korea and China's bilateral trade volume reaches $\$ 235.4$ billion with an increase of $2.8 \%$. South Korean exports to China of $\$ 145.33$ billion and imports $\$ 90.07$ billion from China. China has become the largest trading partner, the largest export destination and the largest import source of South Korea. South Korea is the third largest trading partner of China.

Foreign trade being entering into the transitional period, international market demand being not prosperous, domestic export industry being less competitive, trade friction taking place frequently, all these increasing resistance not only bring challenges to our foreign trade enterprises but also new opportunities at the same time. The characteristics of our economy new normal ,that is "stabilizing growth, adjusting structure , improving quality", determine that foreign trade enterprises should abandon the past practice such as blindly pursuing increment, extensive growth, relying on traditional labor-intensive industrial advantage and pursue quality efficiency type intensive growth, adjust the stock, optimize increments, dig new growth points of foreign trade. Industrial structure should shift from labor-intensive industries to hightech industries and build the whole industrial chain. Diversifying market development especially pay more attention to the emerging markets such as Southeast Asian nations (ASEAN), South Korea, Russia, Brazil and diversifying the modes of trade to get rid of excessive reliance on processing trade put forward higher requirements in foreign trade talent demand for the foreign trade industry .

By the end of 2013, accumulated 56224 South Korea's projects invest in China and the actual investment amount reaches $\$ 55.95$ billion. South Korea is the fourth largest foreign direct investment source of China. In 2013, China's nonfinancial direct investment to South Korea amounts to \$250 million, rising 121.4 per cent year-on-year. By the end of 2013 
China's total investment to South Korea amounts to \$1.24 billion. President Park Geun-hye visited to China and talked with Chairman Xi Jin-ping and Premier Li Ke-qiang in 2013. The two sides published "China and South Korea joint statement for the future". The relationship between China and South Korea rose sharply.

The increasing development of exchanges between China and South Korea promote the social demand for Korean talent rapidly.

From the regional distribution, the demand for Korea talent in opening-up coastal cities and developed regions such as the Yangtze river delta, the Pearl River Delta, the Northeast region, Jiaodong Peninsula, which is the city existing geopolitical relations with South Korea, is more urgent than that in other places. But with the rise of the "China craze" in South Korea and the promotion of China and South Korea tourism, many South Korean go to China for learning Chinese culture and sightseeing. South Korean's footprint distribution in the mainland of China appear the trend from centralizing to decentralizing [2].

From the industrial distribution, Korean talent demand mainly distributes in the primary industry and tertiary industry. South Korea investments in China focus on manufacturing. A lot of enterprises are small and medium businesses undertaking textile and garment, toys, shoes, leather processing and other labor-intensive industry. Later in the 1990s, mechanical and electrical, automotive, chemical and other technology-intensive and capital-intensive business investment increased rapidly. In recent years as the constraints of environmental resources, the policies and regulations as well as increasingly intensified competition from European and local companies, South Korea's high-tech enterprises increased rapidly, mainly distributing in electronics, communication, automobile, shipbuilding, electrical and mechanical, shipping and logistics industry. The tertiary industry mainly includes department stores, hotels and tourism.

From the view of enterprise demand, the Korean companies to staff training investment is less, the localization of enterprise level is not high. Most positions of enterprise such as managers and business executives are engaged by Korean people and Chinese have few opportunities for promotion. So many earlier enterprises have to close or withdrawal their investment. In recent years, Korean companies in China has enhanced their localization consciousness and recruited all kinds of talent. A few years ago most position offered were business assistant, interpreter etc. Now the enterprises need more Chinese local talent to be engaged in primary management, research and even higher position. South Korean companies used to recruit energetic young people with strong learning ability and adaptive capacity. Most of the enterprises require the age of employee is not over 30 years old, a few scarce talent or technical person being extended. South Korean companies prefer to compound talents owning some kinds of technology such as machinery, electronics, chemical engineering, especially semiconductor microelectronic materials talent.

In short, the trend of Korean talent demand has shifted from the quantity pursuing to higher quality requirements, from the junior talent to professional talents. The Korean talent should master not only some technology but also sociability, not only Korean language skills but also social-cultural knowledge.

\section{Cultivation LocAtion IN THE NeW NormaL}

By the foregoing analysis, the market demand for Korean talent is divided into the following three types: (1) high-level academic talent; (2) compound Korean professionals; (3) skill practical talents. High-level academic talent focused on administrative-type units, including the Foreign Affairs Office, the Overseas Chinese Affairs Office, consulates, foreign economic and trade, scientific research institutes and universities, and professional translation services. The absolute number of personnel demand is relatively small in this regard. Most Korean people are concentrated in joint ventures and trade companies. Skill practical talents are mainly those lacking undergraduate training, graduating from vocational college mainly based on skills training, the emphasis is practical ability rather than the ability of taking exams. Composite professionals refer to mastering a foreign language and another a specialized knowledge, such as professional talents of foreign trade, financial, law, computer, tourism, communications, business management, shipping and other expertise.

A few years ago, skills and practical talents are very popular with South Korean firms. This was closely connected with the Korean industry shift, South Korean enterprises' technical-level in China and China's comparative advantage to the Korean business trade. But with fierce competition of foreign firms in China and industrial technology upgrading as well as trade policy and environmental regulations restriction, South Korean companies have increasingly recognized the introduction of compound talents.

Under the new normal trade situation, the urgent demand talents of Korean companies in China are composite talents who not only know Korean, but also master the rules of international trade, international commercial law, also, they should know Korean talk to South Korean people by understanding cross-cultural communication, and can participate in the negotiations and personnel management decisions.

Korean, as a kind of minority language, the source of talent has its particularity. Korean people in my country from four aspects: First, hundreds of Korean domestic professional cultivating college graduates opened. Most of this part of the Korean people are halfway decent learn Korean, the lack of language skills, but the high overall quality, high level of expertise. Second, the country has about 2 million ethnic Koreans, Korean language is, most people have skills, but to accept a certain number of people with higher education and skills training is being reduced. Third, Chinese students studying in Korea, and basically had no language problems, but also to learn some professional knowledge of Korean society and political culture, customs better understanding. However, the number of returned overseas students and in the same year from Korea Korean-related work is very limited. Fourth, there are about 1 million a year or so Korean in China, study, travel and work. Most of them belong to the compound Korean people [3]. 
According to the analysis, although people who know Korean are within the ranks of large-scale and its number have been able to basically meet the market demand. But the talent level of quality varies, skilled personnel side, a serious shortage of high-level and complex talent from the professional standard for the Korean community demand a certain gap. This is in terms of the culture of Korean professionals of colleges and universities are both a challenge and an opportunity, the key is to be able to accurately locate Korean training objectives.

Such ordinary colleges as Xuzhou Institute of Technology for example, in consideration of whether its Korean language teachers or Korean students' language foundation, it is not appropriate to locate the Korean professional training in the "high-level, research-oriented, academic". Considering Korean professional practice skills instructor, associate degree "double" proportion, lack of experimental training facilities, professional settings and the local economy is weak, the lack of effective mechanisms of mutual integration between schools and enterprises, and so, too, suitable for positioning in the development of skills and practical talents. It is recommended that Korean personnel training targeting the "compound" talent.

So what kind of talent is compound talent? The current consensus is: "compound talents refer both to mastering the skills of a foreign language, know the language for basic knowledge, but also has multi-skill talent basic knowledge and skills in a discipline other. " Korean Compound Talents Training Korean speaking and writing proficiency and other skills are not required must be proficient, you can basically meet the social demand. Other subjects may refer to a practice of international trade, business negotiation, law, tourism management, hotel management, machinery manufacturing, electronic telecommunications and other disciplines.

To cultivate compound Korean professional talents is obviously a challenge for both teachers and students. The teacher's own teaching literacy, teaching philosophy, knowledge and skills are required to have a higher level; students should master a Korean in just four years, but also to master knowledge of other disciplines and skills, in terms of time and they are required to pay a huge effort. Of course, located in cultivating talent, not completely negate the "academic" and "skilled" personnel training, after all the students than waking condition, few students committed to "academic" talent development or go according to their "practical skills-based" growth pathways, which college located in the "complex" Training does not contradict with[4].

\section{TAlEnt TRAining StRATEGy IN THE NEW NORMAL}

"Compound" Korean talents cultivation is complicated system engineering, here are some suggestions:

How to position, how to meet the needs of society, what kind of Korean professional talents as the goal, all these are the most important questions for higher vocational education development. Korean professional talents cultivation in higher vocational colleges should be based upon talents demands of locality, the whole nation and all social aspects. According to the demand of society, vigorously training practical primary industry and tertiary industry, service-oriented Korean professional talents should be vigorously developed. It should be apart from the training goal of research-based and academicbased talent cultivating.

After training target positioning, it is important to pay attention to the curriculum system constructing. Korean language course design should be modular, three-dimensional, hierarchical, pay attention to cultivate students' solid language foundation, give consideration to the promotion of cultural literacy, social skills. Interdisciplinary course module settings should consider the market demand, students' career planning and learning interest, appropriately increase the proportion of "professional elective courses" with "optional courses", pay attention to the coordination of language courses.

Talent cultivation needs abundant, quality excellent teachers to safeguard, given the current Korean professional teachers being shortage, the present situation of the quality not higher, the teachers staff construction is also a very important task. It is necessary to pay attention to the construction and guarantee system of professional teacher staff. To cultivate compound talents requires a high level and high quality teaching staff. Teachers' academic level and social experience and practice level determine the success or failure of compound talents training. Universities should scientifically introduce Korean teaching talents and design teaching courses according to the actual situation and the social demands as the guidance, should constantly adjust teachers' knowledge structure.

According to the compound talent growth rules, it is necessary to design reasonably the phases of Korean comprehensive ability training, complex ability training, theory with practice ability training so as to ensure the continuity, scientifity, systematicness and structural integrity of compound talents cultivation. In addition, schools should guarantee hardware and software facilities related to teaching and set up the interactive mechanism not only of schools and enterprises, but of schools and local economic construction.

\section{REFERENCES}

[1] http://countryreport.mofcom.gov.cn/record/view110209.asp?news_id=4 2573

[2] Sun Geng-mei, Zhao Xiao-xia. Make foreign language talent become auxiliary wing of foreign enterprises [J]. Commercial culture, 2012 (3) : 35-36.

[3] Wang Jian-jun. survey report on present situation of compound foreign language talents demand-Tangshan city as an example [J]. Journal of Tangshan vocational technical college, 2010(2): 11-14.

[4] Wen Zhong-zhe, Jin Shun-jie. Nalysis of social demand for Korean professional talents and training target design[J]. Journal of International studies, 2006 (11): 192-193. 